\title{
The Alaska Salmon Enhancement Program: A Cost/Benefit Analysis
}

\author{
JOHN BOYCE* \\ MARK HERRMANN* \\ DIANE BISCHAK $\dagger$ \\ JOSHUA GREENBERG ${ }^{\circledR}$
}

\author{
*Department of Economics \\ $\dagger$ Department of Business Administration \\ ${ }^{\circledR}$ Department of Resource Economics \\ University of Alaska Fairbanks \\ Fairbanks, Alaska 99775
}

\begin{abstract}
In May 1991, the Alaska Senate's Special Committee on Domestic and International Commercial Fisheries initiated the first review of the state's salmon enhancement program since its inception 20 years ago. As part of this review, a cost/benefit analysis of the State's enhancement program for salmon was performed with cooperation from the Fisheries Research Enhancement Division of the Alaska Department of Fish and Game. The main results are that the additional producer's surplus generated by the pink and sockeye hatchery programs are estimated to be less than the costs of running these programs. Eliminating the entire pink or sockeye salmon programs is estimated to increase net benefits by about $8 \%$ and $6 \%$, respectively. A $15 \%$ increase in either program is estimated to result in a reduction in net benefits and a $15 \%$ decrease in either program is estimated to result in a slight increase in net benefits. Estimates of the confidence intervals for net benefits suggest that the gains from the elimination of either the pink program or the sockeye program are statistically different from zero. However, changes of plus or minus $15 \%$ of current hatchery production are found not to statistically affect net benefits.
\end{abstract}

Keywords cost, benefit, Alaska, salmon, hatchery

\section{Introduction}

When the enhancement program in Alaska was initiated in the early 1970s, North American wild Pacific salmon dominated world salmon markets. With Alaskan salmon supplies dwindling, but with oil revenues high, Alaska started a salmon enhancement program to increase salmon stocks and to invest in a renewable resource that would bring the state revenues long after oil supplies were exhausted. Since then, there has been a rapid rise in the supply of salmon worldwide. The worldwide increase in production is primarily the result of large in-

This paper is a result of research sponsored with funds from the Alaska State Senate Special Committee on Domestic and International Commercial Fisheries, Alaska Sea Grant with funds from the National Oceanic and Atmospheric Administration, Office of Sea Grant, Department of Commerce, under grant no. NA90AA-D-SG066, project \#R/14-13, and from the University of Alaska Faculty Small Grants Program. 
creases in farmed salmon production. However, in Alaska, record harvests have also been recorded, in part due to production from the enhancement program, in which the state has invested considerable funds, and in part due to healthy harvests of wild stocks. With the increasing supply, the prices received by Alaska fishers for salmon have plummeted (see Table 1). With farming countries such as Chile increasing supply, and Russia becoming a player on world markets, it appears that supplies of salmon on the world markets are more likely to continue to increase than to decrease (see Table 2). Recent studies have suggested that the single largest downward pressure on salmon prices has been increases in wild and farmed salmon supplies (Herrmann 1992).

Partially in response to the supply concern, the Alaska Legislature's Senate Special Committee on Domestic and International Commercial Fisheries contracted for a cost-benefit analysis as part of its first comprehensive review of the state's enhancement program. Of interest were all five species of Pacific salmon (sockeye, chinook, coho, chum, and pink salmon) for the salmon enhancement regions of Prince William Sound, Cook Inlet, Kodiak, and Southeast (see Figure 1). ${ }^{1}$ This paper is the third and last in a series measuring the net benefits of the Alaska salmon enhancement program. The first paper, entitled "Using Participation Rates to Estimate Fishing Costs," estimated the costs to fishers fishing for salmon in the above regions (Boyce 1993). The second paper, entitled "Using an International Econometric Model to Forecast Alaska Salmon Revenues," forecasts revenues generated under various scenarios for the Alaska salmon enhancement program (Herrmann 1993). Results from these two papers, along with estimated hatchery costs, are used to derive the net benefit to Alaska of continuing at various salmon enhancement levels.

\section{Brief History of Alaska Salmon Enhancement}

When the Alaska salmon enhancement program was developed by the State in the 1970 s, Alaska salmon runs had been in decline since 1936. The average annual harvest number of salmon from 1945 to 1975 was 83 million fish; however, for the last 15 years of this period the average annual catch was just 45 million fish. Between 1973 and 1975 the catch was only 23 million fish annually. The start of the Alaska hatchery system can be traced back to 1968, when concerned Alaska citizens approved a $\$ 3$ million bond issue to construct state hatcheries. In 1969, as Alaska received $\$ 900$ million from North Slope oil and gas leases, it decided to pursue the investment of public funds from nonrenewable resources (oil and gas) into development of renewable resources to provide a long-term source of employment and economic activity. The legislature's goal was to protect and supplement wild stocks through production until a total goal of 100 million fish was reached (Alaska State Senate 1992).

On May 28, 1971 the Division of Fisheries Rehabilitation, Enhancement, and Development (FRED) within the Alaska Department of Fish and Game (ADF\&G) was created to start up and manage the state's hatcheries and to promote private hatcheries. With $\$ 10.5$ million in 1974 from a bond issuance, FRED was able to initiate its program of building and maintaining several hatchery systems. At this

${ }^{1}$ These articles examine only the two most important Alaska salmon species, sockeye and pink. 
Table 1

Alaska Salmon Harvest Volume, Harvest Value, and Exvessel Prices, 1980-1991

Alaska Harvest Volume (million pounds)

\begin{tabular}{|c|c|c|c|c|c|c|c|c|c|c|c|c|c|}
\hline Fishery & 1980 & 1981 & 1982 & 1983 & 1984 & 1985 & 1986 & 1987 & 1988 & 1989 & 1990 & 1991 & Average \\
\hline Chinook & 12.5 & 15.7 & 16.9 & 15.7 & 12.5 & 15.5 & 11.7 & 13.3 & 10.9 & 11.3 & 11.5 & 10.7 & 13.2 \\
\hline Sockeye & 186.7 & 226.0 & 188.6 & 305.6 & 222.7 & 221.5 & 194.6 & 224.8 & 188.6 & 260.7 & 306.0 & 259.0 & 232.1 \\
\hline Coho & 22.4 & 25.8 & 46.5 & 26.8 & 44.5 & 47.3 & 46.6 & 25.3 & 35.5 & 33.2 & 40.0 & 43.9 & 36.5 \\
\hline Pink & 217.9 & 245.0 & 219.1 & 194.1 & 276.7 & 304.3 & 259.3 & 164.8 & 177.9 & 331.5 & 271.9 & 349.3 & 251.0 \\
\hline Chum & 71.8 & 99.5 & 91.2 & 79.1 & 104.1 & 83.4 & 97.1 & 80.4 & 121.6 & 61.6 & 62.7 & 66.3 & 84.9 \\
\hline TOTAL & 511.3 & 612.0 & 562.3 & 621.3 & 660.5 & 672.0 & 609.3 & 508.6 & 534.5 & 698.3 & 692.1 & 729.2 & 617.6 \\
\hline \multicolumn{14}{|c|}{ Alaska Harvest Value (million dollars) } \\
\hline Fishery & 1980 & 1981 & 1982 & 1983 & 1984 & 1985 & 1986 & 1987 & 1988 & 1989 & 1990 & 1991 & Average \\
\hline Chinook & 17.8 & 23.7 & 27.0 & 18.2 & 21.8 & 20.8 & 17.8 & 26.8 & 29.6 & 20.9 & 21.5 & 20.4 & 22.2 \\
\hline Sockeye & 109.5 & 196.3 & 155.9 & 212.8 & 171.9 & 218.2 & 278.0 & 348.2 & 443.2 & 369.9 & 393.0 & 199.1 & 258.0 \\
\hline Coho & 17.9 & 23.7 & 40.0 & 16.2 & 42.7 & 42.6 & 42.0 & 28.8 & 61.8 & 27.1 & 40.5 & 29.5 & 34.4 \\
\hline Pink & 77.1 & 106.0 & 47.5 & 48.0 & 70.5 & 71.9 & 62.0 & 69.1 & 141.3 & 144.7 & 90.8 & 44.3 & 81.1 \\
\hline Chum & 32.1 & 47.6 & 39.2 & 25.0 & 36.3 & 33.0 & 34.4 & 37.1 & 105.5 & 24.4 & 28.4 & 18.4 & 38.5 \\
\hline TOTAL & 254.4 & 397.3 & 309.6 & 320.2 & 343.2 & 386.5 & 434.2 & 510.0 & 781.4 & 587.0 & 574.2 & 311.7 & 434.1 \\
\hline \multicolumn{14}{|c|}{ Alaska Exvessel Prices (dollars/pound) } \\
\hline Fishery & 1980 & 1981 & 1982 & 1983 & 1984 & 1985 & 1986 & 1987 & 1988 & 1989 & 1990 & 1991 & Average \\
\hline Chinook & 1.42 & 1.51 & 1.60 & 1.16 & 1.74 & 1.54 & 1.52 & 2.02 & 2.71 & 1.85 & 1.88 & 1.90 & 1.74 \\
\hline Sockeye & 0.59 & 0.87 & 0.83 & 0.70 & 0.77 & 0.99 & 1.43 & 1.55 & 2.35 & 1.42 & 1.28 & 0.77 & 1.13 \\
\hline Coho & 0.80 & 0.92 & 0.86 & 0.60 & .90 & 0.90 & 0.90 & 1.14 & 1.74 & 0.82 & 1.01 & 0.67 & 0.94 \\
\hline Pink & 0.35 & 0.43 & 0.22 & & 0.25 & 0.24 & 0.24 & 0.42 & 0.79 & 0.44 & 0.33 & 0.13 & 0.34 \\
\hline Chum & 0.45 & 0.48 & 0.43 & 0.32 & 0.35 & 0.40 & 0.35 & 0.46 & 0.87 & 0.40 & 0.45 & 0.28 & 0.44 \\
\hline
\end{tabular}

Source: University of Alaska, Alaska Salmon Markets, May 1992. 
Table 2

World Salmon Harvest Volume 1980-1991 (million pounds and percents)

\begin{tabular}{lccccccccccccc}
\hline & 1980 & 1981 & 1982 & 1983 & 1984 & 1985 & 1986 & 1987 & 1988 & 1989 & 1990 & 1991 & Average \\
\hline Alaska Wild & 511 & 612 & 562 & 621 & 661 & 672 & 609 & 509 & 535 & 698 & 692 & 729 & 618 \\
Russia Wild & 219 & 238 & 148 & 295 & 179 & 291 & 174 & 305 & 179 & 400 & 264 & 554 & 270 \\
World Farmed & 15 & 26 & 33 & 48 & 74 & 102 & 156 & 210 & 319 & 479 & 621 & - & - \\
\% Alaska Wild & $41 \%$ & $44 \%$ & $43 \%$ & $31 \%$ & $44 \%$ & $34 \%$ & $41 \%$ & $33 \%$ & $30 \%$ & $34 \%$ & $29 \%$ & - & - \\
\% Russia Wild & $18 \%$ & $17 \%$ & $11 \%$ & $18 \%$ & $12 \%$ & $15 \%$ & $12 \%$ & $22 \%$ & $10 \%$ & $19 \%$ & $13 \%$ & - & - \\
\% World Farmed & $1 \%$ & $2 \%$ & $3 \%$ & $3 \%$ & $5 \%$ & $5 \%$ & $11 \%$ & $14 \%$ & $18 \%$ & $22 \%$ & $28 \%$ & - & - \\
TOTAL $^{\text {a }}$ & 1242 & 1379 & 1307 & 1595 & 1512 & 1948 & 1458 & 1390 & 1726 & 2089 & 2056 & - & \\
\hline
\end{tabular}

a 'Total includes all other countries' production not reported.

Source: Alaska Salmon Marketing Institute, Salmon 2000, March 1991. Streletsky, Andrei, "Russian Far East and Alaska Fishery," Unpublished Paper, University of Alaska Fairbanks, December 1992. University of Alaska, Alaska Salmon Markets, May 1992. 


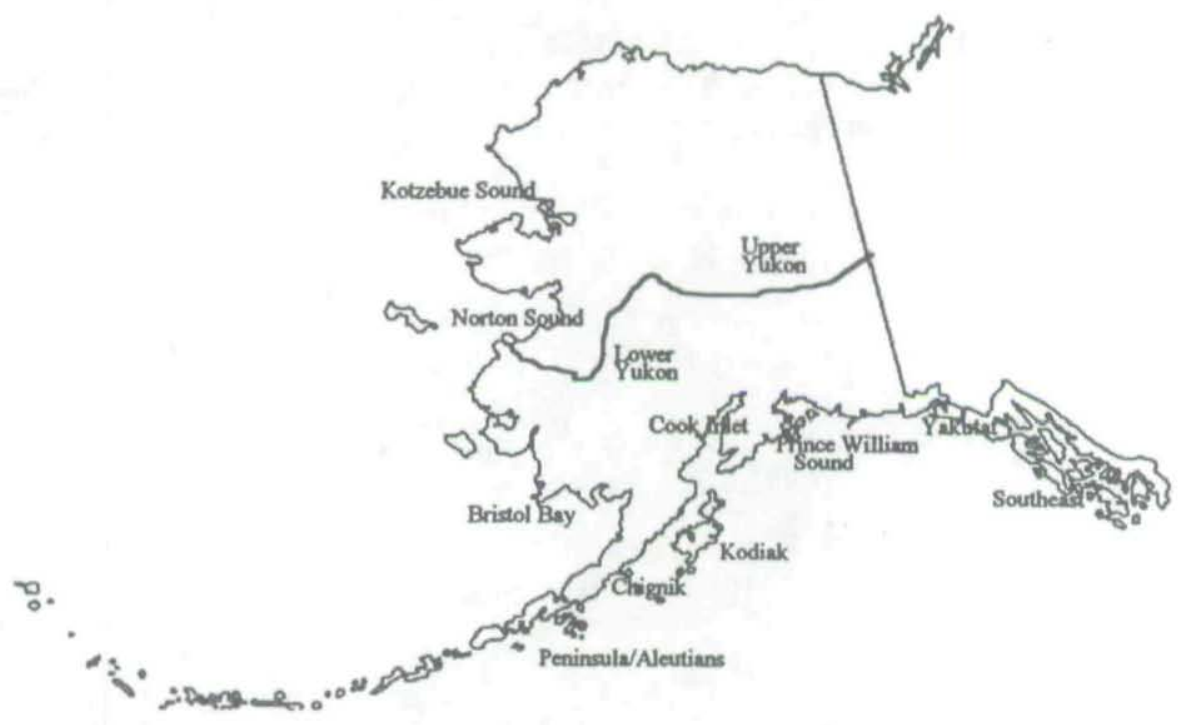

Figure 1. Major salmon producing regions in Alaska.

time the state legislature estimated that a total investment of \$200 million from both state and private sources was required to develop the entire fishery resource. The private component of the enhancement program was to be composed of private non-profit (PNP) hatcheries. Currently there are 37 salmon hatcheries operating in Alaska. The FRED division operates 12 of these hatcheries and the PNPs manage 25 (although four of these are owned by the State). The 1990 returns from the FRED hatcheries were 6.3 million fish and returns from PNPs were 42.3 million. ${ }^{2}$ Hatchery fish represented 24 percent of total salmon returns in 1990 (University of Alaska 1992). ${ }^{3}$ During the 20 years of creating and managing hatcheries, the State did not formally consider the economic benefits or consequences of increasing the salmon supplies in making its investment and production decisions.

\section{Hatchery Funding}

State funding for FRED's enhancement operations have come from a variety of sources. Bond issues totaled \$56.17 million. Capital appropriations totaled \$24.8 million. \$20 million has been transferred by the state to FRED as part of the Pacific Salmon Treaty. The State's total 1972-1992 appropriation to FRED was $\$ 210.3$ million. PNPs may be funded through four separate sources. Regional Aquaculture associations may tax members 1 to 3 percent of the exvessel value of salmon landings (for use in the region's hatcheries). Funds may be borrowed from the state-administered Enhancement Revolving Loan Fund. ${ }^{4}$ State grants are pe-

${ }^{2}$ The returns to FRED hatcheries are proportionally lower because many of FREDs hatcheries emphasize research while PNPs mainly emphasize commercial activities.

${ }^{3}$ Currently about 25 to 45 percent of Alaskan pink salmon harvests originate from hatchery fish (depending on cycle) and approximately 20 to 25 percent of all Alaska salmon harvest in weight originate from hatchery fish.

${ }^{4}$ The maximum available loan to a PNP is $\$ 10$ million at approximately $9.5 \%$ interest with 
riodically made available for private hatchery projects. Finally, a cost recovery system is used to fund the PNP hatcheries. Under this system, hatcheries offset production costs by harvesting hatchery salmon and selling them on the open market.

Through 1991 PNP expenditures have totaled slightly over \$200 million. The amount and percentage of funding by the various sources are shown below.

$\begin{array}{ll}\text { \$71.0 million } & 35 \text { percent State Loans } \\ \text { \$12.3 million } & 7 \text { percent General Fund Grants } \\ \text { \$46.2 million } & 23 \text { percent Enhancement Tax Assessments } \\ \text { \$70.9 million } & 35 \text { percent Cost Recovery Sales of Fish } \\ \text { \$200.4 million } & \text { Total }\end{array}$

State funding has accounted for 42 percent of the PNP's total budget. Currently, 95\% (\$67.7 million) of state loans are still outstanding (State of Alaska 1992).

\section{Research Objectives}

This cost/benefit analysis uses a state accounting stance which means that only the benefits and costs occurring in Alaska were considered. For example, the benefits to consumers in other parts of the U.S. or in other world markets were not considered. This does not imply that these benefits do not exist but that they are not captured by the state of Alaska. ${ }^{5}$ This paper examines 7 of the original 17 alternative hatchery production scenarios, as mandated by the state. These are provided in Table 3.

For each alternative, the 30-year average of projections for catch, revenues, producers' surplus, hatchery costs, and net benefits are reported. ${ }^{6}$ All dollar figures are expressed in 1992 dollars, however the figures presented are the undiscounted averages. ${ }^{7}$ For each alternative, we report projections for 1) Western Alaska, ${ }^{8}$ 2) Cook Inlet, 3) Kodiak, 4) Prince William Sound, 5) Southeast Alaska, and 6) the state's total.

The revenue data in each table represents the projected gross returns to the region or to the state from the salmon fishery. The estimated cost to fishermen used in the analysis represents the opportunity costs of participating in a particular salmon fishery, i.e., it is the value foregone by participating in the salmon fishery rather than the next most valuable activity. Accordingly, fishermen costs

a playback period of up to 30 years. In addition, interest on the loans does not start accruing until 6 to 10 years into the loan.

${ }^{5}$ The term Alaska and state of Alaska are used broadly to reflect the public of Alaska and not just the state government.

${ }^{6}$ Although the revenue analysis only predicted revenues for 15 years, the 30 year predictions were made by assuming that the real revenues generated for years $16-30$ were the same as the average for years $11-15$.

${ }^{7}$ We examined the cases of zero, four and seven percent "real" discount rates (i.e. we removed the inflation part of the interest rate). Only the $0 \%$ discount rate figures are used in the analysis. The $4 \%$ and $7 \%$ discount figures change magnitudes, but do not alter the relative scenario rankings. This is because the costs and benefits of each alternative are relatively evenly distributed over the planning horizon.

${ }^{8}$ This region is comprised of Bristol Bay, the Peninsula/Aleutians, Kuskokwim, Norton Sound, Upper and Lower Yukon, and Kotzebue (see figure 1). There is little or no hatchery fish output in these areas. By far the largest fishery here is Bristol Bay. 
Table 3

The Alternatives Considered in the Policy Analysis

Case 1 Maintain current enhancement production

Case 2 Eliminate entire pink salmon enhancement production

Case 3 Eliminate entire sockeye salmon enhancement production

Case 4 Increase pink salmon enhancement production level by $15 \%$

Case 5 Decrease pink salmon enhancement production level by $15 \%$

Case 6 Increase sockeye salmon enhancement production level by $15 \%$

Case 7 Decrease sockeye salmon enhancement production level by $15 \%$

were estimated as the minimum level of returns required before the fishermen would participate in a particular fishery. These costs are real economic costs since they would have earned returns equal to the value of their next best alternative if they had not been active in a particular fishery (Boyce 1993). ${ }^{9}$ Salmon enhancement program expenditures represent the cost of providing these net benefits to fishermen.

\section{Research Methods}

The cost/benefit analysis consisted of five parts:

- SALMON POPULATION AND EXPLOITATION MODEL: estimated the quantity of harvestable fish given enhancement production levels,

- INTERNATIONAL SALMON DEMAND MODEL: estimated prices and revenues given the biological model's projections of harvestable fish and assumptions about worldwide production and demand changes,

- COMMERCIAL SALMON FISHING COST MODEL: estimated the net returns to fishermen given the quantity and revenues attainable from the catchable fish,

- SALMON ENHANCEMENT costs: used hatchery operators' estimates of the costs to produce the enhanced production levels, and

- SALMON ENHANCEMENT SIMULATION MODEL: summarized the effects of each of the previous four models.

The models were used to generate projections for a 30-year planning horizon. The first three models (biological, demand, and fishing cost) are described in detail in Boyce 1993, Collie 1992, and Herrmann 1993, respectively. For each management alternative, biological stock projections were generated. Population estimates were projected for wild and farmed salmon in Prince William Sound pink salmon, Cook Inlet sockeye salmon, Kodiak sockeye and pink salmon, and Southeast king salmon. Other production estimates were developed by facility operators and by $A D F \& G$. These biological projections were then used in an international salmon demand model to project salmon prices for the various species/region combinations (Herrmann and Greenberg, 1992). The quantity and price

${ }^{9}$ It is inappropriate to simply view the cost part of the revenues as benefits because they represent expenditures to the other sectors of the state. While it is true that they represent expenditures to other sectors, they also represent what was foregone by the fishermen if they had been engaged in their next best alternative. 
projections were then used to estimate the costs to fishermen of participating in the fishery (Boyce, 1993).

Two net benefit measures were of interest. First, the net benefits to fishermen from the salmon enhancement program are defined as the return above fishermen's costs. Second, the net benefits to the state are represented by the estimated fishermen's net benefits less the costs of running the enhancement program. These costs are comprised of enhancement facility costs and ADF\&G administrative support and management costs. The hatcheries were surveyed to determine their current actual costs and their expected costs if enhancement production was increased or decreased. All enhancement program costs were provided by the FRED division.

We considered fishermen's producers' surplus to be the appropriate measure of the benefits to fishermen. Producers' surplus measures the return above variable costs to fishermen. If the fisherman does not expect to earn revenues higher than his or her next best alternative, then they choose not to fish. Any returns they receive above the minimum required to attract them into the fishery is their producers' surplus. The net benefits to the state of the enhancement program is the net benefits to the fishermen, as measured by producers' surplus, minus the enhancement costs. This measure indicates the net benefits to fishermen above the costs of providing these benefits.

\section{Results}

\section{Differences in Catch among the Alternatives}

Salmon run sizes and catches under each of the enhancement program alternatives were estimated by Collie (1992). The total predicted catches for all species (wild and hatchery) averaged across the 30-year planning horizon are provided in Table 4 . The differences in the averages between the alternative cases represent the net difference in total salmon enhancement production.

Changes in the enhancement program significantly impact total harvests. Under current hatchery production (case 1), the 30 year projected harvest is 23,333 million pounds, or an average annual harvest of 778 million pounds. This forecast is greater than the 1991 production of 729 million pounds, and generally represents

\section{Table 4}

Average Annual Total Commercial Catch by Enhancement Alternative (millions of pounds, thirty year average)

\begin{tabular}{ccccccc}
\hline Case & $\begin{array}{c}\text { Western } \\
\text { Alaska }\end{array}$ & $\begin{array}{c}\text { Cook } \\
\text { Inlet }\end{array}$ & Kodiak & $\begin{array}{c}\text { Prince } \\
\text { William } \\
\text { Sound }\end{array}$ & Southeast & $\begin{array}{c}\text { State-wide } \\
\text { Total }\end{array}$ \\
\hline 1 & 260.88 & 56.69 & 81.04 & 174.69 & 205.09 & 778.39 \\
2 & 260.88 & 45.35 & 71.33 & 73.55 & 197.32 & 648.42 \\
3 & 260.88 & 53.38 & 75.66 & 167.12 & 204.08 & 761.11 \\
4 & 260.88 & 58.39 & 82.51 & 189.66 & 206.26 & 797.70 \\
5 & 260.88 & 54.99 & 79.83 & 160.00 & 203.93 & 759.62 \\
6 & 260.88 & 57.24 & 81.78 & 175.69 & 205.23 & 780.81 \\
7 & 260.88 & 56.17 & 80.27 & 173.69 & 204.96 & 775.97 \\
\hline
\end{tabular}


an optimistic projection of future enhanced and wild salmon populations. This increase from the 1991 levels is, however, less than the 218 million pound increase in salmon harvest that took place from 1980 to 1991 . There is some speculation that ocean temperatures may cool in the future, dampening future increases in run sizes or even reducing run sizes.

Comparison of total harvest under case 2 (eliminate pink enhancement program) and case 3 (eliminate sockeye enhancement program) shows that enhancement production of pinks is much greater than sockeye enhancement production. Elimination of the entire pink salmon program would lead to a projected $16.6 \%$ reduction in total commercial catch of all species. Commercial catch would be reduced by a projected $2.2 \%$ if the sockeye salmon program were eliminated.

There are also regional differences in production levels of the enhancement program. There are no enhanced pinks or sockeyes produced in Western Alaska. Cook Inlet hatcheries account for approximately $20 \%$ of total pink salmon harvest and $6 \%$ of sockeye salmon harvest. Kodiak hatcheries account for $12 \%$ of current pink salmon harvest, and $7 \%$ of sockeye salmon harvest. Approximately $42 \%$ of Prince William Sound pink harvest is comprised of hatchery stocks. Hatchery production there also accounts for $4 \%$ of the sockeye salmon harvest. Hatchery stocks comprise only $3.8 \%$ of Southeast's pink harvest and $0.5 \%$ of the sockeye harvest. The Prince William Sound commercial salmon fishery is the most dependent upon enhancement production. Western Alaska is the least dependent.

\section{Differences in total revenues among the alternatives}

Proportional increases in catch do not imply proportional increases in gross revenues. Revenues depend upon both quantities and prices. Revenues may either increase or decrease for a quantity change in either direction. A more thorough discussion of the revenue effects is contained in the discussion of the market model (Herrmann and Greenberg, 1992). However, a summary of the projected revenue differences between the alternatives is provided in Table 5 .

Elimination of the pink enhancement program (case 2) increases revenues in the Western Alaska, Kodiak, and Southeast fisheries and decreases revenues in the Cook Inlet and Prince William Sound fisheries. The declines in gross revenues (to Cook Inlet and Prince William Sound) exceed the increases in gross revenues

\section{Table 5}

Average Annual Total Gross Revenues by Enhancement Alternative (millions of 1992 dollars, thirty year average)

\begin{tabular}{ccccccc}
\hline Case & $\begin{array}{c}\text { Western } \\
\text { Alaska }\end{array}$ & $\begin{array}{c}\text { Cook } \\
\text { Inlet }\end{array}$ & Kodiak & $\begin{array}{c}\text { Prince } \\
\text { William } \\
\text { Sound }\end{array}$ & Southeast & $\begin{array}{c}\text { State-wide } \\
\text { Total }\end{array}$ \\
\hline 1 & 244.68 & 53.67 & 51.15 & 85.59 & 121.69 & 556.78 \\
2 & 250.77 & 51.41 & 53.89 & 57.57 & 136.62 & 550.26 \\
3 & 257.04 & 50.59 & 44.48 & 74.03 & 121.89 & 548.03 \\
4 & 243.86 & 53.78 & 50.50 & 86.93 & 119.27 & 554.34 \\
5 & 245.49 & 53.49 & 51.80 & 83.56 & 123.99 & 558.33 \\
6 & 243.02 & 54.20 & 51.98 & 87.03 & 121.66 & 557.89 \\
7 & 246.37 & 53.17 & 50.25 & 84.12 & 121.73 & 555.64 \\
\hline
\end{tabular}


to the other regions. Elimination of the sockeye salmon (case 3) also has a net negative effect on total gross revenues relative to the current status quo, with only Western Alaska showing projected revenue gains.

Cases $4,5,6$, and 7 examine effects of $15 \%$ increases in enhancement production and $15 \%$ decreases in enhancement production for pink and sockeye, respectively. Average annual gross revenues in the sockeye fishery increase with $15 \%$ increases in hatchery production (case 6) and decrease with $15 \%$ decreases in hatchery production (case 7). However, a $15 \%$ increase in pink salmon (case 4) causes statewide revenues to decrease (and vice versa, case 5). Total revenue effects are relatively small, with the smallest estimate of average annual gross revenues (case 3 ) being $98.2 \%$ of the largest estimate (case 5). That is, the hatchery program is estimated to affect gross revenues by less than $2 \%$ statewide. However, revenue impacts differ by region in accordance with the contribution of the hatchery production to total harvest. In the case of pink salmon, a $15 \%$ increase in hatchery production benefits Cook Inlet and Prince William Sound fisheries, but decreases revenues in Western Alaska, Kodiak, and Southeast. Eliminating the pink salmon program reduces revenues by $32.7 \%$ in Prince William Sound, and eliminating the sockeye salmon program reduces revenues in Kodiak by $13 \%$ and in Cook Inlet by $5.7 \%$.

Western Alaska is the only sockeye salmon fishery which experiences decreases (increases) in gross revenues when sockeye salmon hatchery production is increased (decreased) by $15 \%$ (cases 6 and 7). This is because there is no sockeye hatchery production in Western Alaska. Therefore, the effect of an increase in sockeye elsewhere simply has a price effect in Western Alaska. Statewide, $15 \%$ increases in sockeye hatchery production boosts sockeye gross revenues.

\section{Differences in Producers' Surplus among the Alternatives}

When all else is held constant, higher revenues are preferred to lower revenues. However, all else is not held constant. An alternative may result in increased revenues because price has increased or because harvest has increased. These two cases are not identical in the way fishermen perceive them. A revenue increase which results from increases in price alone for a particular region will result in different cost effects than a revenue increase due to increases in harvests alone. Furthermore, increases in catch of a particular species may either increase or decrease costs, depending upon whether the fleet is geared to target the particular species or whether the catch of that species is incidental to the targeting of other species. For instance, in Cook Inlet, where hatchery raised pink salmon comprise almost $20 \%$ of the total catch, when pink salmon are eliminated, costs of fishing are estimated to increase since the loss in producer's surplus is greater than the loss in revenues. However, in Kodiak, where hatchery raised pink salmon comprise only about $12 \%$ of the total catch, the cost of fishing is estimated to decrease when pink salmon are eliminated. This appears to be the result of a fleet that is specialized for pink salmon in Cook Inlet and a fleet that is specialized for species other than pink salmon in Kodiak.

These examples suggest that producer's surplus is a better measure of the welfare of fishermen than is gross revenues. Estimates of producer's surplus by alternative and by region are contained in Table 6 . In Figure 2, total revenues under common property correspond to the areas $B, C, D, E$ and $F$, with effort at level $E_{C R}$ and the average revenue product (ARP) equal to $A R P_{C R}$. Producer's 
surplus is the area above the marginal effort cost line $M E C$. This corresponds to areas $B, C$ and $D$. If the fishery were prosecuted so as to maximize social welfare, as it is when the cost-recovery fishery is operated, then the effort level would be $E_{C R}$, and the corresponding average revenue product would be $A R P_{C R}$. However, for the hatchery to recover its costs, it must extract the economic rents from the fishermen participating in the cost recovery fishery. It does so by paying the fishermen a smaller price per pound, which shifts the ARP curve down to ARP' in Figure 2. Thus the areas $A$ and $B$ represent the economic rents accrued to the fishery which are used to pay for the hatchery program. The areas $C$ and $D$ represent the revenues to the fishermen participating in the cost recovery fishery, with area $C$ being the producer's surplus retained by fishermen from this fishery. The $M E C$ curve does not shift as a result of the change between the cost recovery fishery and the common property fishery since this measures the opportunity cost

Table 6

Average Annual Producer's Surplus by Enhancement Alternative (millions of 1992 dollars, thirty year average)

\begin{tabular}{|c|c|c|c|c|c|c|c|}
\hline Case & & $\begin{array}{c}\text { Western } \\
\text { Alaska }\end{array}$ & $\begin{array}{l}\text { Cook } \\
\text { Inlet }\end{array}$ & Kodiak & $\begin{array}{l}\text { Prince } \\
\text { William } \\
\text { Sound }\end{array}$ & Southeast & $\begin{array}{c}\text { State-wide } \\
\text { Total }\end{array}$ \\
\hline \multirow[t]{3}{*}{1} & & 114.14 & 36.23 & 14.63 & 18.78 & 38.57 & 222.34 \\
\hline & ${ }^{a} 5 \%$ & ${ }^{b}-$ & 32.75 & 11.85 & 17.93 & ${ }^{b}-$ & ${ }^{c} 217.79$ \\
\hline & $95 \%$ & - & 39.52 & 17.93 & 19.66 & - & 226.89 \\
\hline \multirow[t]{3}{*}{2} & & 120.23 & 30.96 & 19.57 & 7.75 & 53.50 & 232.01 \\
\hline & $5 \%$ & - & 28.16 & 16.22 & 7.04 & - & 227.94 \\
\hline & $95 \%$ & - & 33.53 & 22.93 & 8.55 & - & 236.11 \\
\hline \multirow[t]{3}{*}{3} & & 126.50 & 33.98 & 15.50 & 16.37 & 38.77 & 231.12 \\
\hline & $5 \%$ & - & 31.25 & 13.21 & 15.67 & - & 227.36 \\
\hline & $95 \%$ & - & 36.80 & 17.29 & 17.10 & - & 234.64 \\
\hline \multirow[t]{3}{*}{4} & & 113.32 & 36.70 & 13.88 & 19.92 & 36.15 & 219.97 \\
\hline & $5 \%$ & - & 33.05 & 11.18 & 19.08 & - & 215.41 \\
\hline & $95 \%$ & - & 40.03 & 16.62 & 20.81 & - & 224.13 \\
\hline \multirow[t]{3}{*}{5} & & 114.95 & 35.76 & 15.24 & 17.46 & 40.87 & 224.29 \\
\hline & $5 \%$ & - & 32.42 & 12.28 & 16.62 & - & 219.63 \\
\hline & $95 \%$ & - & 38.94 & 18.64 & 18.35 & - & 228.81 \\
\hline \multirow[t]{3}{*}{6} & & 112.48 & 36.56 & 14.33 & 19.06 & 38.54 & 220.97 \\
\hline & $5 \%$ & - & 32.81 & 11.59 & 18.20 & - & 216.19 \\
\hline & $95 \%$ & - & 39.89 & 17.33 & 19.97 & - & 225.27 \\
\hline \multirow[t]{3}{*}{7} & & 115.83 & 35.90 & 14.86 & 18.49 & 38.61 & 223.68 \\
\hline & $5 \%$ & - & 32.47 & 11.87 & 17.68 & - & 218.80 \\
\hline & $95 \%$ & - & 39.11 & 18.11 & 19.34 & - & 228.38 \\
\hline
\end{tabular}

${ }^{a}$ The approximate $5 \%$ and $95 \%$ confidence intervals based on 500 iterations using sampling with replacement from the empirical distributions of the reduced form equation errors from Boyce (1993).

${ }^{b}$ No confidence intervals calculated for Southeast and Western Alaska.

${ }^{c}$ The confidence intervals for state-wide are the joint confidence intervals for Cook Inlet, Kodiak, and Prince William Sound. These do not include estimates of variation for Western Alaska or Southeast, and only include the variation due to estimation of resource costs (i.e., variation in revenues due to estimation errors in the demand and biological models is not included). 


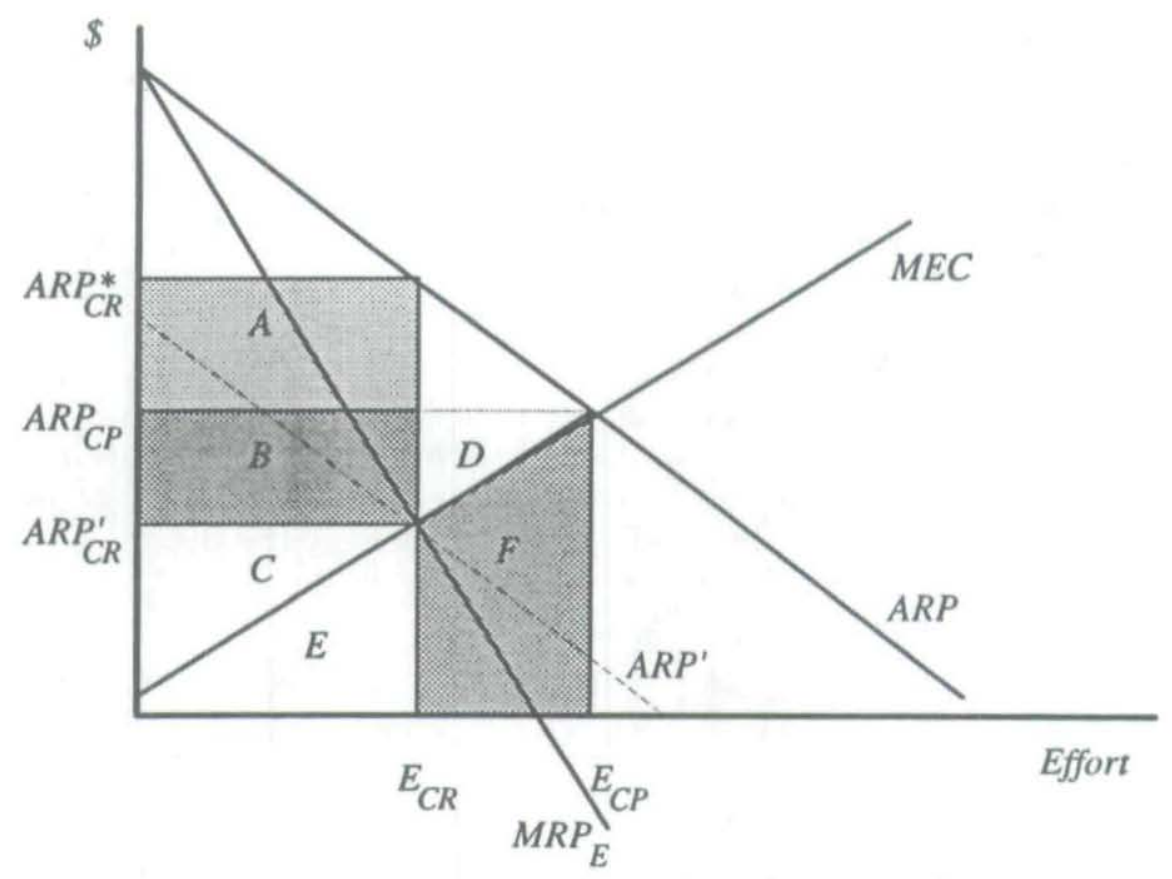

Figure 2. Net benefits calculation.

of fishermen. In the algorithm used to calculate net benefits, the areas $A$ and $B$ represent the part of hatchery costs which are subtracted from producer's surplus.

We used the algorithm from Boyce (1993) to estimate resource costs and producer's surplus. For a particular fishery, the cost model with parameters estimated with 1990 data was used to estimate fishing costs if the fishery had experienced the ex-vessel prices and season harvest quantities by species predicted by the biological and demand models. It was assumed that the harvest returns by species were proportional to the harvest returns in 1990. That is, for each fishing day in 1990, the available harvest was inflated by the ratio of projected harvest for year $t$ relative to 1990 harvest. This was done for each species. The available harvest was the aggregate across species. Prices were assumed to be the predicted prices from the demand model. The cost model was used to predict the number of participants and the average revenues per participant. From this information an estimate of producer's surplus was obtained. A representation of the algorithm is given in Appendix A.

Boyce (1993) estimated fishing cost model parameters for 9 fisheries: Cook Inlet purse seine, drift net, and set net; Prince William Sound drift net and purse seine; Kodiak purse seine and set net; and the Southeast hand and power troll fisheries. ${ }^{10}$ The cost model for these fisheries is exactly as estimated by Boyce. For the remaining fisheries, an extrapolation was made. For the Prince William Sound set net fishery, which contributes only 1 to 2 percent of the entire Prince

${ }^{10}$ These were the only fisheries for which data was provided to the researchers for cost examination. Fisheries for which no fishing cost model parameters exist are: Western Alaska drift net, purse seine, and set net; Prince William Sound set net; and Southeast drift net, purse seine, and set net. 
William Sound salmon catch, producer's surplus was calculated using the average of producer's surplus estimates created by using the Cook Inlet and Kodiak set net fleet's cost model parameters using Prince William Sound catch and price data,

The producer's surplus estimates for Western Alaska and Southeast were calculated assuming that the producer surplus changes for each scenario were identical to changes in gross revenues. The reasoning is as follows. Since Western Alaska has no hatchery output, the only changes that occur are the result of price changes. This causes the average revenue product of effort function to shift, but does not affect costs. In Southeast, hatchery production is less than $4 \%$ of pink catch and less than $1 \%$ of sockeye catch. Therefore, changes in hatchery production in Southeast should have negligible effects on both catch and fishing costs. However, as with Western Alaska, changes in state-wide hatchery production affect prices and hence revenues. The estimate of the base case (case 1) producer's surplus for Southeast and Western Alaska fisheries was calculated as follows. The average of the ratio of producer's surplus to total revenues by fleet for similar fleets was calculated under the assumption that prices were the same as in Western Alaska or Southeast, respectively, but quantities were the same as in the original fleets. ${ }^{11}$ This average of the ratio of producer's surplus to total revenues by fleet was then multiplied by the total revenues in the Western Alaska and Southeast fleets to obtain an estimate of producer's surplus by fleet. ${ }^{12}$ The estimate of producer's surplus by fleet was summed over the fleets in the region to obtain the point estimate of producer's surplus for the region.

The data in Table 6 shows that the effects of the various enhancement alternatives are considerably dampened, and in a few cases directionally reversed, when producers' surplus is used as the welfare measure rather than total revenues. The difference between the base case (case 1) and with eliminating the pink salmon enhancement program (case 2 ) is a reduction of about $\$ 9.67$ million per year on average over the thirty years, a decrease of about $4 \%$. Eliminating the sockeye salmon program (case 3 ) reduces producer's surplus by about $\$ 8.78$ million per year on average. Fifteen percent increases in pink salmon are estimated to decrease producer's surplus by $\$ 2.37$ million per year on average and a fifteen percent decrease in pink salmon is estimated to cause producer's surplus to rise by $\$ 1.95$ million, in each case a change of approximately $1 \%$. Fifteen percent increases or decreases in sockeye hatchery production move in the same direction as for pink salmon, but are slightly smaller. A fifteen percent increase in sockeye is estimated to decrease producer's surplus by $\$ 1.37$ million per year on average statewide, and a fifteen percent decrease is estimated to increase statewide producer's surplus by $\$ 1.34$ million per year on average.

The estimates in Table 6 are the median estimate obtained from 500 simulation experiments. In each experiment the empirical distribution of errors from the fishing cost model reduced form equations are used to simulate a new set of instrumental variables for the two-stage-least-squares (2SLS) model. First, the

${ }^{11}$ I.e., the Western Alaska and Southeast drift net, purse seine, and set net fleet's estimates of producer's surplus were calculated using producer's surplus estimates from the Cook Inlet and Prince William Sound drift net fleets, purse seine, and set nets, respectively. The Southeast hand and power troll fleets used the cost parameters for those fleets. ${ }^{12}$ This was necessitated because the differences in harvest between the fleets in different regions was well beyond the bounds for which the cost models had been estimated. 
reduced form estimates of average revenues and effort participation are generated using the estimated quantities and prices from the demand and biological models. Second, a vector of disturbances is drawn (with replacement) from the distribution of reduced form errors and added to the reduced form estimates of effort and participation. Third, the two-stage-least-squares estimates of effort, average revenue, and producer's surplus are calculated using the price and quantity data from the demand and biological models and using the reduced form equation estimates of effort and participation plus the draw from the empirical distribution of random disturbances. This allows for an approximate $90 \%$ confidence interval to be estimated for the producer's surplus estimates. The confidence intervals were calculated only for the regions for which empirical distributions of the reduced form equations existed (i.e., Cook Inlet, Kodiak, and Prince William Sound). ${ }^{13}$ The $90 \%$ confidence interval is the observed $5 \%$ and $95 \%$ points in the empirical distribution of producer's surplus. For each experiment, the state-wide total is the sum of the producer's surplus over the different regions. ${ }^{14}$ The state-wide joint confidence interval is the observed $5 \%$ and $95 \%$ points of the empirical distributions of the sums across regions. It is conditional upon the demand and biological model estimates and upon the point estimates of producer's surplus for Western Alaska and Southeast.

The estimated confidence intervals are reported in Table 6 . Using a nonoverlapping-confidence-interval criterion, the base case (case 1) is observed to be statistically different (at the $90 \%$ confidence level) from either of the elimination cases (cases 2 and 3), but not statistically different from any of the fifteen percent changes cases (cases 4 through 7). That is, elimination of either pinks or reds causes a statistically significant rise in producer's surplus. Even though the changes are only a magnitude of about $4 \%$, the changes appear to be statistically significant.

The changes in producers' surplus for pink and sockeye salmon fifteen percent increases and decreases are similar in sign to the effect of changes in revenues. Increased pink salmon hatchery production helps the Prince William Sound and Cook Inlet pink fisheries, and higher sockeye salmon enhancement production helps both of these regions as well as Kodiak. Both Western Alaska and Southeast have reductions (increases) in producers' surplus from increases (decreases) of either pink or sockeye salmon.

\section{Enhancement Costs Under the Different Alternatives}

In this section, the costs of generating the producers' surplus benefits to the fishermen are considered. The measured enhancement costs correspond to the area $\mathrm{A}$ in Figure Two. ${ }^{15}$ As mentioned previously, these enhancement costs do not include cost recovery costs (areas B and D), which are considered revenues

${ }^{13}$ The confidence intervals for the Prince William Sound set net fleet were calculated using the average from the Cook Inlet and Kodiak set net fleets.

${ }_{14}$ The estimates for Western Alaska and Southeast did not vary across experiment since no empirical distributions of errors existed for these fisheries.

${ }^{15}$ The "cost-recovery" harvest is done by competitive bidding. The hatchery keeps area A for cost recovery, and pays fishermen areas B and D to harvest the fish. The competitive bidding process will drive price down to the point where the marginal participant in the cost-recovery fishery will earn zero economic rents. Assuming that the common property 


\section{Table 7}

Average Annual Hatchery Costs by Enhancement Alternative (millions of 1992 dollars, thirty year average)

\begin{tabular}{ccccccc}
\hline Case & $\begin{array}{c}\text { Western } \\
\text { Alaska }\end{array}$ & $\begin{array}{c}\text { Cook } \\
\text { Inlet }\end{array}$ & Kodiak & $\begin{array}{c}\text { Prince } \\
\text { William } \\
\text { Sound }\end{array}$ & Southeast & $\begin{array}{c}\text { State-wide } \\
\text { Total }\end{array}$ \\
\hline 1 & 0.00 & 1.90 & 1.63 & 10.39 & 9.51 & 23.43 \\
2 & 0.00 & 1.38 & 1.24 & 5.82 & 8.63 & 17.06 \\
3 & 0.00 & 0.71 & 1.07 & 8.83 & 8.71 & 19.32 \\
4 & 0.00 & 1.91 & 1.82 & 11.22 & 9.77 & 24.71 \\
5 & 0.00 & 1.82 & 1.57 & 9.70 & 9.38 & 22.47 \\
6 & 0.00 & 2.04 & 1.70 & 10.59 & 10.06 & 24.38 \\
7 & 0.00 & 1.72 & 1.55 & 10.16 & 9.39 & 22.81 \\
\hline
\end{tabular}

to the fishermen. The reported hatchery costs are contained in Table 7. They are also expressed in millions of 1992 dollars and as 30-year averages. ${ }^{16}$

The estimated annual cost of running the enhancement program at current levels is $\$ 23.43$ million. The most expensive alternative is case 4 , in which the pink salmon enhancement is increased by $15 \%$. This would result in costs increasing to $\$ 24.71$ million, or a $5.5 \%$ cost increase. The greatest cost savings is achieved by eliminating the pink salmon enhancement program (case 2). This would result in average annual costs of $\$ 17.06$ million, or a $27 \%$ decrease in costs. Elimination of the sockeye salmon hatchery program would result in average annual costs of $\$ 19.32$ million, or a decrease of $17.5 \%$. Note also that for the $15 \%$ increases or decreases, the increases change costs proportionately more than the decreases, which is consistent with rising marginal costs.

Inspection of Table 7 indicates the regional differences in the enhancement program. Prince William Sound and Southeast account for almost $85 \%$ of the current hatchery costs. Cook Inlet and Kodiak account for the balance, with slightly more spent in Cook Inlet than Kodiak. Western Alaska has insignificant costs relative to the other regions. ${ }^{17}$ Pink salmon production accounts for almost $50 \%$ of the costs in Prince William Sound, and sockeye salmon accounts for about a quarter of the costs in Cook Inlet and Kodiak.

All cost data represent facility operators' estimates of costs under the various alternatives. There is reason to believe that the costs may be overstated for a number of the reduction scenarios. For example, the cost savings from elimination of the pink program is a $27 \%$ reduction. Cost savings from elimination of the sockeye salmon program result in a savings of $18 \%$. Thus, elimination of the two largest programs reduces costs by less than $40 \%$ according to the operators. This

fishery estimates of opportunity cost accurately measure opportunity cost, the equilibrium will be such that area A completely recovers the hatchery costs.

${ }^{16}$ The hatchery costs for each alternative are relatively stable over time.

${ }^{17}$ Western Alaska costs are not included at all. The one hatchery in Western Alaska did not respond to the hatchery cost survey. The costs in Prince William Sound are less accurate than for the other regions because the facility in Valdez did not report costs for its pink or chum operations. We used Prince William Sound Aquaculture Corporation data to estimate Valdez costs and adjusted costs in proportion to Valdez production levels. All of the costs are aggregates for the region, and may conceal differences across facilities. 
appears to imply that there are costs which must be incurred whether or not production of a particular species occurs. The only way to eliminate those costs appears to be to close the entire facility. It is likely that faced with such an option, other cost savings would appear.

\section{Net Benefits under the Different Alternatives}

The net benefits in Table 8 , are derived by subtracting the enhancement costs of Table 7 from the producers' surplus estimates of Table 6. Again, all values are expressed in 1992 dollars and are the annual average over the thirty year planning horizon. The confidence intervals are calculated by subtracting the estimate of enhancement costs from the confidence intervals for the producer's surplus.

Under current enhancement levels, the average annual value of returns to the state from the commercial salmon fishery is estimated to be $\$ 198.91$ million over the next thirty years. If the pink salmon program is eliminated, given the current market structure, the state is projected to earn net returns of $\$ 214.95$ million per year over the 30 -year planning horizon, an increase of about $8 \%$ per year. If the sockeye hatchery program is eliminated, net returns are predicted to be $\$ 211.80$ million, an increase of about $6 \%$. Fifteen percent increases in either pink or sockeye salmon are estimated to reduce net benefits slightly ( $1 \%$ or less) relative to current output levels, and fifteen percent decreases are estimated to increase net benefits slightly ( $1 \%$ or less). The changes in the sockeye salmon program are estimated to have smaller impacts than changes in the pink salmon hatchery program.

At the state-wide level, the $90 \%$ confidence interval of net benefits for the base case (case 1) is $\$ 194.36$ to $\$ 203.46$ million per year, about plus or minus two percent. The $90 \%$ confidence interval for both the eliminate pinks alternative (case 2) and eliminate sockeye alternative (case 3) do not overlap with the base case confidence interval. We conclude that both elimination alternatives are statistically different from the base case. However, the fifteen percent changes alternatives (cases 4 through 7) confidence intervals do overlap with the base case alternative and in each case the confidence interval for one contains the mean for the other. We conclude that these cases do not result in changes that are statistically significant.

Table 8

Average Annual Net Benefits by Enhancement Alternative (millions of 1992 dollars, thirty year average)

\begin{tabular}{ccccccc}
\hline Case & $\begin{array}{c}\text { Western } \\
\text { Alaska }\end{array}$ & $\begin{array}{c}\text { Cook } \\
\text { Inlet }\end{array}$ & Kodiak & $\begin{array}{c}\text { Prince } \\
\text { William } \\
\text { Sound }\end{array}$ & Southeast & $\begin{array}{c}\text { State-wide } \\
\text { Total }\end{array}$ \\
\hline 1 & 114.14 & 34.33 & 13.00 & 8.39 & 29.06 & 198.91 \\
2 & 120.23 & 29.58 & 18.33 & 1.93 & 44.87 & 214.95 \\
3 & 126.50 & 33.27 & 14.43 & 7.54 & 30.06 & 211.80 \\
4 & 113.32 & 34.79 & 12.06 & 8.70 & 26.38 & 195.26 \\
5 & 114.95 & 33.94 & 13.67 & 7.76 & 31.49 & 201.82 \\
6 & 112.48 & 34.52 & 12.63 & 8.47 & 28.48 & 196.59 \\
7 & 115.83 & 34.18 & 13.31 & 8.33 & 29.22 & 200.87 \\
\hline
\end{tabular}


The regional differences are quite small proportional changes for all cases except elimination of the pink salmon program. Elimination of the pink salmon program is estimated to reduce net benefits in Prince William Sound by over $80 \%$, down to $\$ 1.93$ million per year from $\$ 8.39$ million per year. In contrast, in Kodiak, elimination of the pink salmon program statewide results in a $40 \%$ increase in average annual net benefits, up to $\$ 18.33$ million per year from $\$ 13.00$ million per year under the current hatchery production levels. The two largest salmon producing regions, Western Alaska (dominated by Bristol Bay) and Southeast generally show increases in net benefits from decreases in state-wide pink and sockeye hatchery operations.

\section{Discussion of Findings}

None of the alternatives involving increases in enhancement production for sockeye or pink salmon is estimated to increase projected net benefits to the state. On the other hand, reduction or elimination of either the pink or sockeye salmon enhancement programs resulted in increases in net benefits statewide. Furthermore, the point estimates of net benefits suggest that the hatchery program provides only very small changes in the net benefits to the state. Regionally, the enhancement program is estimated to have a dramatically positive effect only in Prince William Sound, where elimination of the pink salmon program is estimated to reduce net benefits to approximately $20 \%$ of their current levels. However, this appears to be more than offset by gains made elsewhere in the state. For sockeye salmon, Western Alaska (Bristol Bay) gains from sockeye enhancement reductions are greater than losses occurring to Prince William Sound and Cook Inlet.

The confidence intervals suggest that either of the elimination alternatives (case 2 or 3 ) result in a statistically significant increase in net benefits to the state. Conversely, neither a $15 \%$ reduction nor a $15 \%$ increase in the pink or sockeye salmon hatchery production is found to statistically affect net benefits relative to the current level of hatchery production. This suggests that large reductions in hatchery output either in pinks or sockeye are the only actions the state can take to increase net benefits.

The estimated confidence intervals take into account only the variation associated with the fishing cost models. Variation in the demand and biological models is explicitly excluded as is variation in the producer's surplus for fisheries for which no direct cost model data existed. Inclusion of variation from these models would tend to increase the confidence intervals. We would suggest that future research concentrate on obtaining estimates of the variation from these models and on obtaining direct estimates of fishing costs in the fisheries not included in this study.

There is good reason to believe that our estimates of hatchery cost savings from elimination of either the pink or sockeye programs are understated. These species make up more than $90 \%$ of hatchery output. However, elimination of both the pink and sockeye programs together results in average annual cost savings of only about $\$ 10.48$ million per year, or about $45 \%$ of the base case annual average.

If the state reduces or discontinues funding of the enhancement program, production of fish for sport and subsistence purposes will most likely not continue without some state funding. We have made no effort to analyze the net benefits from hatchery production on other user groups. Our estimates of hatchery costs also included hatchery costs only for production of fish for commercial purposes. 
To estimate more fully the benefits and costs to other user groups, the state would have to determine the net benefits to those groups. ${ }^{18}$

There also may be strategic reasons for maintaining hatchery production. For example, it appears that hatchery exports of Russian pink salmon may be expanding as are farmed salmon exports from Chile. By maintaining some Alaska hatchery production, prices may remain sufficiently depressed to prevent expansion in those areas. As long as the price is not driven down to the level that it would reach if these other producers entered the market, the hatchery dollars may be well spent. However, this is not a strategy which can remain viable over the long run.

Finally, let us emphasize that the projected net benefits were based on parameters estimated from models for which only a brief data time period was available. The forecasts were extrapolated well beyond the time horizon for which accurate estimates may be obtained. ${ }^{19}$ There are also a number of exogenous factors, such as what is happening in the rest of the salmon suppliers' markets, that have changed far too rapidly over the last decade to allow precise estimates of where the industry will be in one, two or three decades.

\section{Appendix A: The Cost/Benefit Algorithm}

Do Region Cook Inlet to Prince William Sound

Do Fishery Drift Net to Set Net

Do Year 1992 to 2006

STEP 1: Generate StockProxy and AvePrice variables for Fishery and Year

Harvest(Fishery, Year,Day) $=$

$$
\text { Harvest(Fishery,1990,Day) } * \frac{\text { Quantity(Fishery,Year) }}{\text { Quantity(Fishery,1990) }}
$$

StockProxy(Fishery, Year,Day $)=\sum_{i=0}^{3}$ Harvest $($ Fishery, Year,Day $+i) / 2^{i}$

$$
\begin{aligned}
& \text { StockProxy(Fishery,Year,Day })= \\
& \quad \beta(\text { StockProxy, 1990) }
\end{aligned}
$$

$\widehat{\text { Price }(\text { Fishery,Year,Day) }=}$

$$
\frac{\sum_{\text {species }=1}^{5} \text { Price(Fishery,Year,Day)*Harvest(Fishery,Year,Day) }}{\sum_{\text {species }=1}^{5} \text { Harvest(Fishery,Year,Day) }}
$$

${ }^{18}$ However, for pink salmon this is not really an issue.

19 The long time period was used at the state's request. 
STEP 2: Generate Reduced Form equation estimates for Effort and Average Revenues

AveRevenues(Fishery, Year,Day) $=$

$$
\Pi(\text { AveRevenue, 1990) } * X(\text { ReducedForm exog vars, Year) }
$$

Effort(Fishery, Year,Day) $=$

$\Pi($ Effort,1990) *X(ReducedForm exog vars, Year)

STEP 3: Generate Structural equation estimates for Effort and Average Revenues

AveRevenues(Fishery, Year,Day) $=$

$$
\beta(\text { AveRevenue, 1990) } * X(\text { AveRevenue exog vars, Year) }
$$

$\widehat{\text { Effort }}($ Fishery,Year,Day $)=\beta($ Effort,1990) $* X$ (Effort exog vars, Year $)$

STEP 4: Generate Producer's Surplus estimates

ProdSurplus(Fishery, Year,Day) $=$ $f($ Effort(Fishery,Year,Day),AveRevenues(Fishery, Year,Day))

$\widehat{\text { ProdSurplus(Fishery, Year) }}=\sum_{d=1}^{\mathrm{T}} \hat{\text { ProdSurplus(Fishery, Year,Day })}$

Year $=$ Year +1

Fishery $=$ Next Fishery

$$
\wedge
$$

NetBenefits $($ Region, Year $)=$

$$
\sum_{\text {fishery }=1}^{\mathrm{F}} \widehat{\wedge}_{\text {ProdSurplus(Fishery,Year) - HatcheryCosts(Region, Year) }}
$$

Region $=$ Next Region

\section{References}

Alaska Salmon Marketing Institute. Salmon 2000. 1992.

Alaska State Senate. Legislative Review of the Alaska Salmon Enhancement Program. December 1992.

Boyce, J. Using participation rates to estimate fishing costs. Marine Resource Economics, 8, 1993.

Collie, J. "Salmon Population and Exploitation Modeling." Prepared for the Senate Spe- 
cial Committee on Domestic and International Commercial Fisheries. Juneau, Alaska, February 1993.

Herrmann, M. Using an international econometric model to forecast fishing revenues. Marine Resource Economics 8, 1993.

Herrmann, M. The Alaska salmon price crash of 1991. Arctic Research of the United States. Vol. 6, Fall 1992:34-36.

Herrmann, M. and J. Greenberg. "An international marketing model for Alaska salmonFinal report." Prepared for the Senate Special Committee on Domestic and International Commercial Fisheries. Juneau, Alaska, February 1993.

Gay, Joel. "ADFG Trims Management." Pacific Fishing. March 1993.

SAS Institute, Inc. SAS/ETS User's Guide. Version 5 edition. Cary, NC, 1984.

Streletsky, A., Russian Far East and Alaska fishery. Unpublished paper. University of Alaska Fairbanks, December 1992.

University of Alaska. Alaska Salmon Markets. May 1992. 
Copyright of Marine Resource Economics is the property of Marine Resources Foundation. The copyright in an individual article may be maintained by the author in certain cases. Content may not be copied or emailed to multiple sites or posted to a listserv without the copyright holder's express written permission. However, users may print, download, or email articles for individual use. 